period of magnetic activity, there was for several hours a complete dislocation in short-wave wireless communication between Great Britain and Canada. In point of fact, throughout the period, April 24-29, short wave communication was often impossible on this channel, other channels being variously affected but to a less extent. Cable and Wireless Ltd. also report during the same period frequent interruption due to earth currents in cable circuits operating between Great Britain and Newfoundland and vice versa. On the morning of April 28 between $\mathrm{l}^{\mathrm{h}}$ and $7^{\mathrm{h}}$ and again from $10 \frac{3}{4} \mathrm{~h}$ to $12 \frac{3}{4} \mathrm{~h}$ U.T., the earth currents on this circuit were so severe that transatlantic communication by cable was impossible.

\section{University of London's Institute of Archæology}

ON April 29, the Earl of Athlone, Chancellor of the University of London, formally declared open the Institute of Archæology, housed for the present in St. John's Lodge, Regent's Park, and unveiled wall-tablets to the memory of Mrs. Tessa Verney Wheeler, who was honorary secretary of the original Appeal Committee to collect funds for the foundation of the Institute, and of Mrs. Mary Woodgate Wharrie, a generous benefactor. The Chancellor was welcomed by Sir Charles Peers, chairman of the Committee of Management, and thanks were conveyed to him after the ceremony by the Right Hon. W. G. A. OrmsbyGore, who was First Commissioner of Works when St. John's Lodge, as Crown property, was allotted to the use of the Institute, and Dr. R. E. Mortimer Wheeler, director of the Institute. Arrangements have been made for the tenure of the present premises for a period of years; but it is hoped that eventually quarters for the Institute will be found among the University buildings in Bloomsbury near the Historical Institute and the Institute of Art.

IT is usual on an occasion such as this opening ceremony to describe it as "epoch-making". In the present instance this term might be used with nearer approximation to the truth than is common. As was pointed out at the time, the proposal for an Institute of Archæology in the University of London was first made, the expansion of archæological investigation and the increased interest in the application of its results had made the provision of some such organization as a training ground a matter of urgency. As Sir Charles Peers said in welcoming the Chancellor, archæology, if one of the newest sciences, has the vigour of youth; and although in the nine years which have lapsed since the original proposal was formulated, progress towards meeting the requirements of archæological training may have seemed slow, it has been substantial. The Institute is already well on the way to providing in its library, its collections of antiquities and its training in methods of research the requirements which Sir Charles laid down as the minimum. Lord Athlone's reference to the present importance of Palestine in British field archæology not only emphasizes the value of the collection of Palestinian antiquities-the largest in existence outside Palestine-which the Institute owes to Sir Flinders Petrie and the generosity of the British School of Archæology in Egypt, but also, by endorsing his support of the appeal for a chair of Biblical archæology, afforded convincing testimony that in saying he regarded the ceremony he had just performed as the laying of a foundation stone rather than as a formal opening, he was expressing something more than a conventional compliment.

\section{Celtic and Saxon Art in Early England}

THE exhibition of photographs of stone crosses and other forms of Celtic and Saxon sculptural art in stone now on view in the Iron Age Gallery of the British Museum (Bloomsbury) is an indication of the remarkable wealth of this material still surviving, which, in its mass, is something of a revelation even to the expert. The indefatigable labours of the late Romilly Allen, Baldwin Brown and W. G. Collingwood, the last-named more particularly in the north of England, have made known to archæologists the extent and value of this class of evidence, especially. as afforded by the stone cross, in the interpretation of racial and cultural movement in the early historic period of Britain; but the work of the survey initiated by the Department of British Antiquities of the Museum some eighteen months ago, in which the assistance of the layman and amateur student has been enlisted widely, has brought together a record of examples of the various classes of this art in the form of photographs, which is surprising. As a whole, it is claimed, probably with justice, that this collection of examples of Celtic and Saxon sculptural art is the finest in existence.

SOMETHING of the work which already has been accomplished by the survey is shown in a selection of the photographs, primarily of the stone crosses, but also including fonts, tympana, capitals and the like. Geographically, the area covered is England, with the 'Anglian' crosses of southern Scotland; but selected examples from outside England are shown for purposes of comparison. The Isle of Man and Ireland, important areas which are a study in themselves, naturally are not included. Special features have been made of photographs by John and Mrs. Piper, who have made an extensive collection of photographs of Anglo-Saxon and late Romanesque sculpture, of a group of sculptures from the West Riding of Yorkshire by Mr. J. E. Tetley and of a regional survey of Cheshire and Staffordshire, which is illustrated by distribution maps and a map prepared in collaboration with the School of Geography of the University of Liverpool, showing relation to forest clearance and habitation in the eleventh century.

\section{Armagh Observatory}

Dr. E. M. Lindsay, at present an assistant in the Harvard Observatory in Bloemfontein, South Africa, has been appointed astronomer at Armagh Observatory. This Observatory was founded in the year 1791 by Richard Robinson, Baron Rokeby, Archbishop of Armagh and a great benefactor of the city of 
Armagh. The Primate gave as an endowment of the Observatory twenty acres of land close to Armagh, on which the Observatory is built, and the estate of Derrynaught, which he had bought out of his private means. He further provided for the salary of an assistant and the current expenses of the Observatory. The power of nominating and appointing the astronomer is reserved for the Archbishop of Armagh and Primate of all Ireland for the time being. The first astronomer of the Observatory was the Rer. Dr. J. A. Hamilton, who was succeeded in 1815 by the Rev. W. Davenport, and then, in 1823, by the Rev. T. R. Robinson, who held the post until his death in 1882-a period of more than fifty-eight years. The anemometer which bears Dr. Robinson's name was first put up on the roof of the Observatory in 1846, but meteorological observations had been commenced thirteen years earlier. Dr. J. L. E. Dreyer succeeded Dr. Robinson in 1882, and the next director appointed was Mr. J. A. Hardcastle, who, however, died in 1917 without having actually taken up the post. The Rev. W. F. A. Ellison became director in 1918 and occupied that position until his death at the end of last year.

\section{Royal Institution: Annual Meeting}

THE annual meeting of the members of the Royal Institution was held on Saturday, May 1. In the unavoidable absence of the president, the Right Hon. Lord Eustace Percy, the chair was taken by Major Charles E. S. Phillips, secretary and vice-president. In submitting the annual report of the Visitors to the meeting, the chairman referred to the satisfactory state of the membership, which has increased steadily in recent years, and which stands now, including honorary as well as full members and associate subscribers, at 1,055. The reconstruction of the Library and other rooms, which the Managers were forced to undertake when a large part of the building was found to be in an alarming state of disrepair, was completed in October. This work, which the accounts show had cost nearly $£ 16,000$ at the end of the year, and included the construction of a large new laboratory, has added greatly to the beauty and convenience of the house. Owing to the withdrawal of the direct current mains in Albemarle Street and neighbourhood, it has been necessary for the Institution to provide its own equipment for the supply of direct electric current. A large storage battery and two mercury arc rectifiers, supplied from the A.C. mains, have been installed. The output from the rectifiers has been specially smoothed, and is found to be sufficiently free from ripple for most experimental purposes. The battery is used for are lanterns in the lecture theatre.

THE expenditure on these and other purposes has been largely met from the munificent bequest of the late Mr. Harry Brown, which, it is now reported, has amounted to more than $£ 29,000$. No. 19 Albemarle Street, adjoining the Institution's premises, recently purchased, has now been fully occupied. The two top floors are used for library and museum extension, and the lower floors have been let off for the present, producing income which is being devoted to research purposes. The accounts of the Davy Faraday Re. search Laboratory, in which the Institution's research expenditure is accounted for, show a deficit of nearly $£ 2,000$ on the year's working. The chairman was able to announce a generous Coronation year gift by the honorary secretary of the Laboratory, Sir Robert Mond, of a sum of money sufficient to meet the deficit. The following were elected to the various offices: President: The Right Hon. Lord Eustace Percy. Treasurer: Sir Robert Robertson. Secretary. Major Charles E. S. Phillips. Managers-Sir John Cadman, Sir James Crichton-Browne, Dr. Cecil H. Desch, Sir James Devonshire, Prof. A. C. G. Egerton, Lord Falmouth, Mr. J. S. Highfield, Mr. Arthur Jaffe, Sir William Larke, Mr. V. Warren Low, Sir Murdoch MacDonald, Mr. C. C. Paterson, Prof. J. C. Philip, Sir Thomas Purves and Admiral C. V. Usborne. Visitors-Mr. C. Cuthbertson, Prof. C. L. Fortesque, Dr. J. J. Fox, Captain A. C. Goolden, Prof. H. Hartridge, Mr. Emil Hatschek, Prof. F. L. Hopwood, Dr. R. Lessing, Mr. A. H. Levy, Mr. F. I. G. Rawlins, Mr. Russell J. Reynolds, Prof. H. R. Robinson, Dr. G. Shearer, Major W. S. Tucker and Colonel W. A. Vignoles.

\section{Shakespeare's Universe}

For his Friday evening discourse before the Royal Institution on April 30, Prof. J. Dover Wilson dis. cussed "Shakespeare's Universe". To understand Shakespeare, he said, one must understand his universe-a very different one from that of Newton, and still more from that of Einstein. In his day the ideas of Copernicus and Galileo were just beginning to penetrate to the consciousness of the ordinary man, and did not become really influential until after the middle of the seventeenth century. Shake. speare lived in a universe which, first described by Ptolemæus of Alexandria in the second century A.D., held sway over men's minds throughout the Middle Ages and had thus served humanity for fifteen hundred years. The best picture of this universe in our literature is to be found in "Paradise Lost", for though Milton understood the new astronomy and actually refers in his poem to Galileo, whom he had met in Italy, he made use of the old scheme of ten concentric spheres with the earth at the centre. As the spheres revolved at different rates and with their own peculiar motions on one another, they made music which was known as "the music of the spheres"; the sound was inaudible to mortal ears. Shakespeare's description of this astral musical box is well-known. Thus the universe was a 'harmony' ; and harmony is the master-key of Shakespeare's thinking, whether upon the world at large, upon human society, or upon man himself, man the microcosm which reflected the macrocosm in little.

Music meant a great deal to Shakespeare. It had medicinal properties to which he often refers. Moreover, the man of harmony would be at once fond of music and a good citizen, because human 